(RESEARCH ARTICLE)

\title{
The situational approach in adult education: Modeling situations using the vee diagram
}

\author{
Jamal Barhone, Omar Erradi, Maha Khaldi *, Mohamed Erradi and Mohamed Khaldi \\ Research team in Information Sciences and University Pedagogical Engineering Abdelmalek Essaâdi University, Tetouan, \\ Morocco.
}

Global Journal of Engineering and Technology Advances, 2021, 09(02), 032-042

Publication history: Received on 02 October 2021; revised on 13 November 2021; accepted on 15 November 2021

Article DOI: https://doi.org/10.30574/gjeta.2021.9.2.0146

\begin{abstract}
Much educational research has raised the effectiveness of situational teaching or training aroaches, especially for adult learners in work situations, due to their social and professional nature. The situational aroach (SAP) or situated learning (SL) to refer to the learner, stipulates that learning cannot be isolated from the context of its alications, and that knowledge is insertable from action.

In this context, the situation becomes central in the acquisition of knowledge and the development of capacities and skills, which are now the aims. We therefore deduce that any design, development and implementation of e-learning training for adults is imperatively based on the modelling of the said learning situation.

The objective of this article is to analyze certain models of situations and to propose a model-process more relevant with e-learning training for adults. For the sake of modelling visibility, we use a modified model of the Vee diagram from Gowing's model.
\end{abstract}

Keywords: Learning aroach (AS); Adult e-learning training; Model - process; Modified model of the Vee diagram

\section{Problematic}

Adult learning in formal, informal and even more in the workplace is a difficult field to study because of its contextual, self-directed, implicit and tacit nature. It includes aspects of individual and shared cognition, social interaction and cognitive flexibility. It is the subject of numerous research works in the fields of adult learning, continuing education, training in the workplace and lifelong learning $[1,2,3,45,6]$.

Adult learning is often associated with the situational aroach or the situated learning aroach, insofar as this theory emphasizes the anchoring of knowledge in situations and on relationships and the interactions of learners with their prior knowledge but also because situated learning is strongly dependent on collaborative activities $[7,8]$.

In face-to-face training, it is not mandatory to design a situated learning situation by accounting for all the cognitive, procedural and processing processes that can be generated or implemented during the teaching - learning situation. The spontaneity available to the teacher or expert trainer enables him to detect the various difficulties and to offer the suggestions and the necessary help to the learners $[9,10]$.

\footnotetext{
* Corresponding author: Maha Khaldi

Research team in Information Sciences and University Pedagogical Engineering Abdelmalek Essaâdi university, Tetouan, Morocco. Copyright $(2021$ Author(s) retain the copyright of this article. This article is published under the terms of the Creative Commons Attribution Liscense 4.0.
} 
On the other hand, in e-learning mode, it is up to the computer system and the intelligent virtual tutor to observe and analyze the processes of learner interactions - situation. Therefore, we think, that it is essential for the designer and subsequently for the developer of the learning located online to foresee the different thinking processes, methodological processes and processing processes in order to program the various suggestions, the teaching and didactic aids. And relevant feedback.

The objective of this research work is to propose a model of an online learning situation from an action-oriented perspective, by relying on a modeling diagram which has been shown to be effective in significant learning by numerous researches, which is the Vee diagram.

\section{Theoretical framework}

\subsection{The situation-based aroach in adult training}

Situational aroach, situational didactic, contextual aroach or situated cognition all relate to the same basic theory, situated learning theory $[7,11,12,13,14,15,16,17,18,19]$. This theory was first defined by Brown and colleagues as a teaching model oosing the separation between knowledge and actions, and was then developed and presented by Lave \& Wenger $[20,21]$.

Since then, this theory has been exploited widely in the fields of science education, continuing education, or adult education and lifelong learning [22, 23, 24, 25, 26, 27]. It has enabled researchers, educators or trainers to understand how knowledge is developed, organized and anchored in the memory of learners, or how to aroach representations [28]. The situation-based aroach has made it possible to better understand, analyze and design training programs that make it possible to achieve a good level of learning output [7]. Such was the influence of this theory to the point that some researchers believe that learning can only be meaningful if it is integrated into a social and physical context.

The situated learning theory or situational aroach inspires its foundations from different fields, such as psychology, sociology, cognitive science and anthropology [29]. According to this theory, learning is not isolated from alication contexts, disruptive events, daily habits and problems to be solved. The theory of situated learning or situational learning places the adult learner at the center of a pedagogical model that interacts the following four components: content, tasks or process, context and social community [30].

Agreeing with Lave and Wenger, Norainna points out that situated learning theory suggests that the implementation of effective teaching or training requires the integration of learning into authentic practice contexts, where learners engage in increasingly complex tasks within social communities [31]. Located learning then takes place in a social and collaborative context around a complex learning situation involving shared located cognition and cognitive flexibility.

The concept of competence constitutes the core of the problematic of the theory of situated learning or of the situational aroach. Being competent is knowing how to act in a situation. Competence is built and evolves in situation. The situation then constitutes the purpose of in-service training. It can be deduced that training through situations is based on the principle that a person builds, adapts and develops in situation and in action by relying on his own experiences and preacquired knowledge and on those of others. . The importance is no longer given to the knowledge or skills of the learner but rather to the mobilization of different cognitive, metacognitive and emotional resources in different situations.

The situational or situational learning aroach places learning content in situations, systematically contextualizes them and seeks conditions that allow learners to construct the meaning of their knowledge and aroaches [32]. A meta-analysis of American research published from 1980 to 2004 on the effect of specific science teaching strategies on the success of learners showed that strategies based on the contextualization of learning content and in collaborative mode allow better results in learners [33]. It should be noted, however, that all the theorists of situated aroaches, however varied they may be, agree on the fact that the situation is constitutive of activity and that situations are an integral part of cognition and learning [7]. Further, Mayers \& Freitas used the theory of situated learning as the theoretical foundation for analyzing and understanding learning in web 2.0 environments [34].

By way of summary, we can make a systematic representation of what is the situation-based aroach and the status of the situation in this aroach:

The situated learning and the pedagogical aroach by the situations are anchored in a perspective of human and social development, and are founded on the principle according to which a person builds in interaction, develops and adapts his knowledge and his competences through his experiences. And its actions in a complex and authentic situation; 
The situation is central in this training and learning aroach. Skills are at the heart of this situation. They are its finality.

\subsection{Status of the concept of situation in the perspective of learning by situations}

In pedagogy, situating means giving meaning to learning, placing learners in a contextual framework of learning, involving them in the construction of their learning and the creation of their knowledge. In adult education, situating learning means creating authentic complex situations relevant to the needs of learners.

The journal Recherches en Education devoted a special number to the notion of "learning situation" [35], in which several researchers presented and analyzed the notion of the learning situation from different epistemological, social, but above all didactic angles. .

According to Faerber [36], the learning situation refers to three concepts: a problem stated by the teacher / trainer, a treatment of the problem by learners alone or supervised by the teacher / trainer and a technological, social environment. The learner is in.

All the definitions proposed meet that proposed by Jonnaert and his collaborators in the UNESCO Chair in Curriculum Development [7]: "A situation is a more or less organized complex set of circumstances that a person experiences at a given moment. We cannot exclude the social dimensions of the circumstances of the situations".

An Anglo-Saxon conception made of pragmatism whose finality is human development. In this conception, the relation to the life experiences of the learners is very present, which implies according to this orientation, to place the contents (cognitive, metacognitive, aroaches, techniques, tools ..), the interactions and the context in complex situations and authentic, meaningful to the learner and the community of learners.

There are different typologies of situations; Brousseau [29] classifies situations according to their degree of formality: informal (everyday) situations and formal situations. Faerber [39], for his part, distinguishes between face-to-face and distance learning situations. In the case of adult training, we can draw inspiration from the classification made by Hommage [37]:

Problem situations organized around the crossing of a previously identified obstacle. These "obstacle" situations require the learner to initiate a process of accommodation and adaptation to his environment [38]. The situation must offer sufficient resistance for the learner to reinvest his prior knowledge and representations. However, the situation should not aear to be out of reach, it is in the development proximity zone;

- Integration situations, through which the aim is to aly knowledge and know-how, previously studied as part of a training program;

Key situations: This term is borrowed from the work of Evoquoz which proposes, through scenarios, to assess the key skills particularly in demand in the world of work [39]. These situations are tailor-made and not necessarily related to real situations, even if they involve a certain number of components;

Complex task situations or didactic situations are rooted in the social and cultural reality of learners, in contexts that may really have meaning for them. We will thus ensure to offer learners a rich material environment, made up of authentic documents, manipulable objects of information emanating from multiple sources.

\section{Towards a modelling of learning situations in distance training}

\subsection{The problem of modelling learning situations}

Even if it seems difficult to foresee all the knowledge, all the processes and the interactions that can be generated or put in place by the learning situation, because of its complexity and its status in the perspective of a situated learning. , we can always, by agreeing with Ansaldi to aroach the modelling of a learning situation in order to try to understand how the cognitive, metacognitive and emotional processes unfold, and to identify their real natures in order to arehend the conditions of their effectiveness in a learning situation $[40,41]$.

In pedagogical engineering driven by models, the modelling of distance learning situations will allow the designer of an adult e-learning computer system to anticipate the obstacles and difficulties in learning in order to integrate in the tutor 
systems, the suggestions, the didactic aids but especially the adaptations necessary with the learning styles of the learners.

The literature reveals several attempts at modelling learning situations. Dunkin \& Biddle proposes a situation model "teaching-learning situation in the classroom" bringing into interaction four components the teacher, the learner, the context and the object of the learning, by evoking the different variables inferred in each component [ 42]. We can simplify this model as follows.

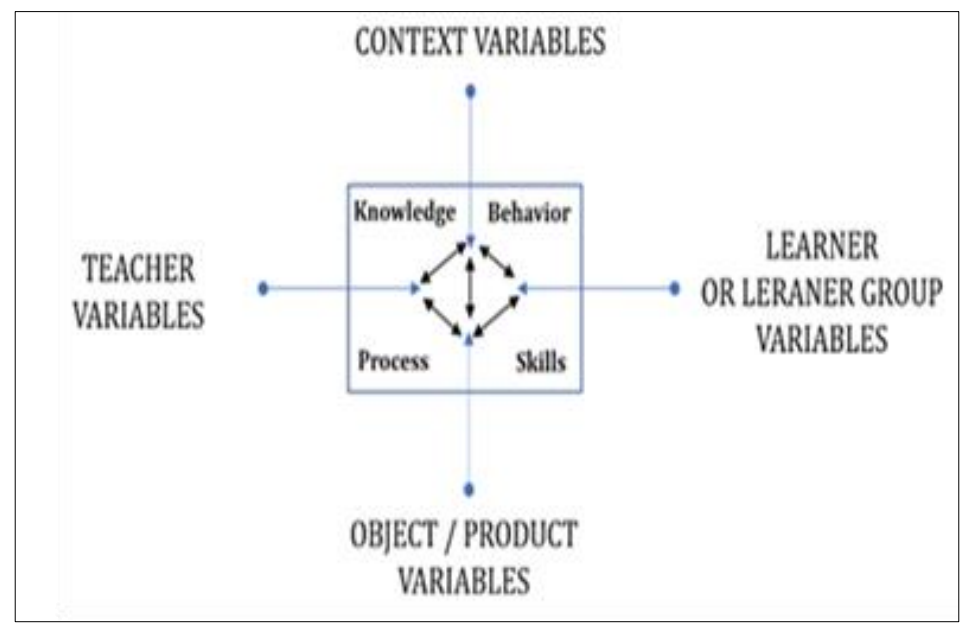

Figure 1 Simplified model of learning situation according to homage [42]

A situation model which by interaction of the four components can generate and develop knowledge, skills, cognitive processes, attitudes and behaviours.

For its part, Gage proposes a process - product model, in which the learning situation is made up of four components which are, the teacher, the situational context, the teaching process and the learner considered in this model by his performance in relation to the situation [43]. The following figure illustrates this model.

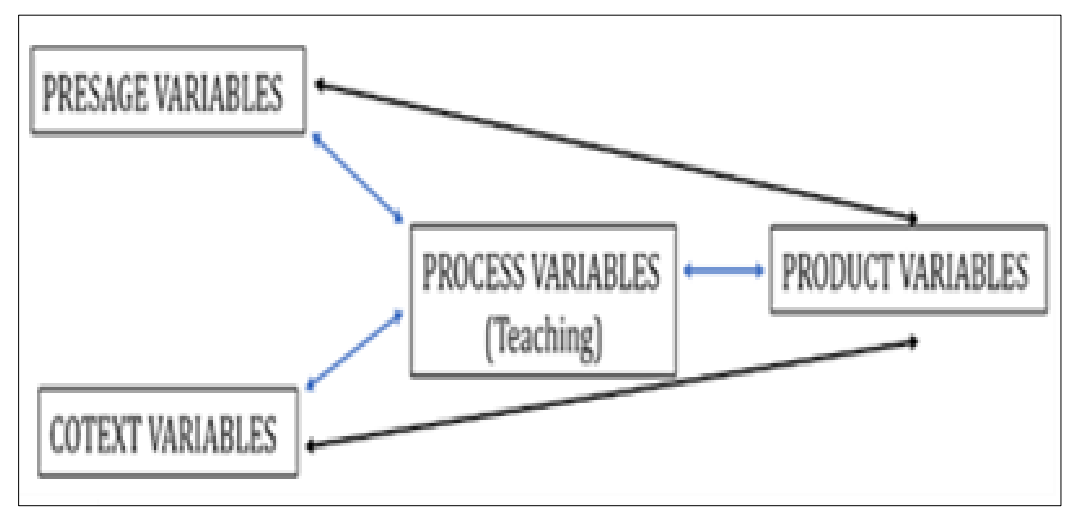

Figure 2 Gage process product model [43]

Another more significant model is proposed by Clanet focusing much more on what the learner will do, highlights the interaction between the teaching processes and the processes of learning from the tasks that will be carried out the learner and the communication actions that will be generated [44]. The following figure illustrates this model.

Derobertmasure \& Dehon have proposed a classroom situation model centered on the relationships and interactions between teacher and learner (s) and which can be very useful in the design and implementation of adult learning situations in the context of 'e-learning training [45]. The following figure illustrates this model.

As for Hérold, he proposes a modelling of the teaching-learning situation from a systemic perspective, taking into account the different interactions between teachers, learners, didactic resources and content to be taught in a given 
environment and where the learner is at the center. of the system, while the teacher is the facilitator [46]. The dynamic and functional aspect of the situation results from the interaction between these different components of the situation. The following figure illustrates this model.

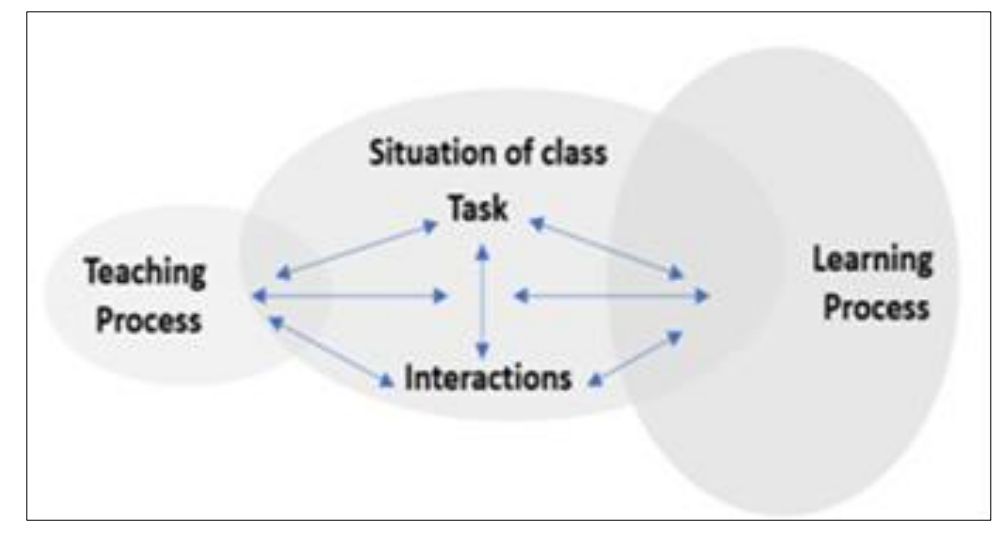

Figure 3 Process teaching model according to clanet [44]

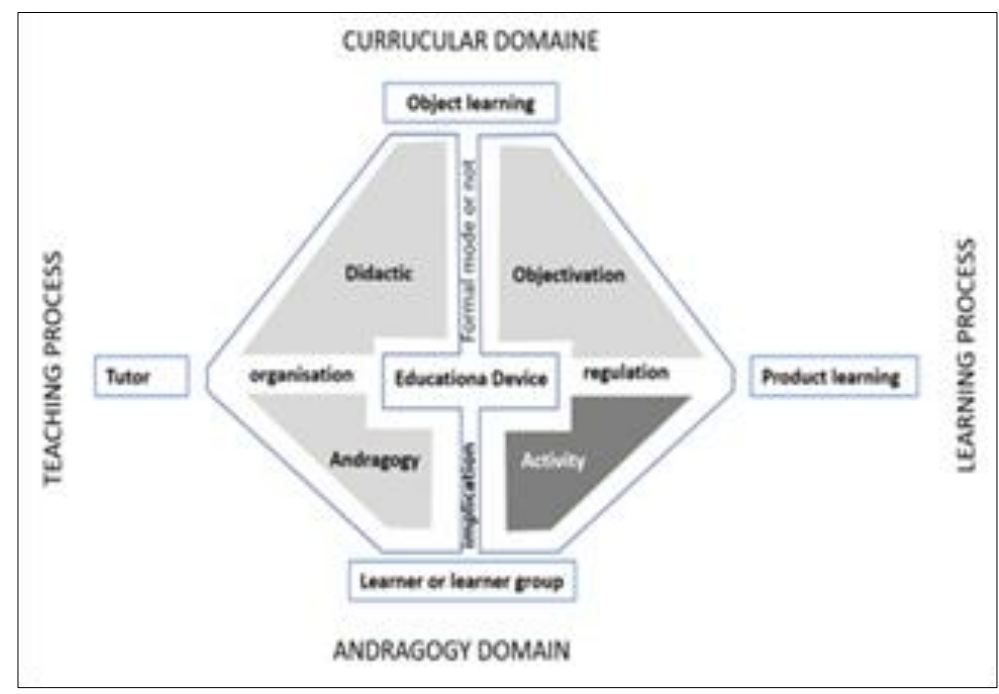

Figure 4 Diagram of tha modified model of teaching/learing practice from derobertmasure \& dehon [45]

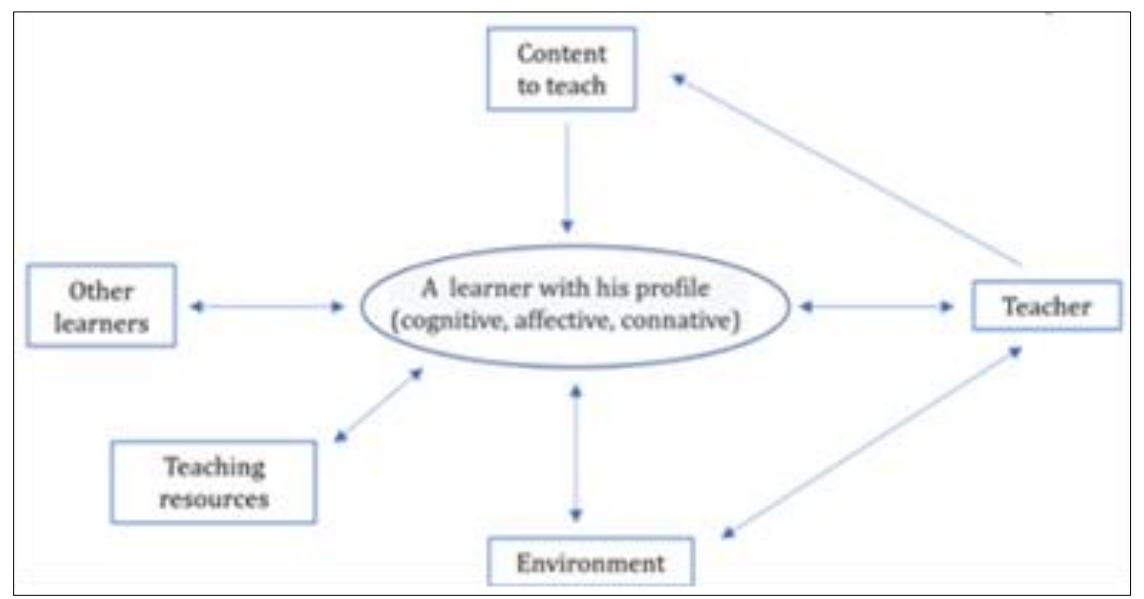

Figure 5 Model of the teaching -learning situation from herold [46] 
Dumont and Istance propose a model of a classroom learning situation, highlighting the dynamics and interactions between four dimensions: the learner, the teacher, the content to be taught and the equipment that will serve as tools. For teaching-learning [47].

Regarding the modelling of learning situations in e-learning mode, very little research has addressed the question of the design and modelling of the learning situation according to a specific perspective or learning aroach, with the aim of to implement it in a computer system. Most of the research has focused on questions of learner modelling, content and eLearning platforms.

By focusing on the modelling of educational activities in an EIAH (computer environment for human learning) concerning reading, Cléder and his collaborators propose a modelling of the situation in terms of knowledge and rules in order to account for the learner activities [48]. This modelling is inspired by the analytical work carried out by Quanquin and Chembreuil in 2006 on the interactions between the computer system and the learner and which gives access to three types of information organizing the representation of the pupil, which are [49]:

- The knowledge to be put in place and their status;

- The cognitive and metacognitive processes to be implemented during the activity;

- Observable behaviours.

- Very recently, Khaldi and his collaborators proposed an architectural model of the e-learning learning situation integrating four dimensions [50]:

- Learner profile;

- Skills to perform;

- Specific knowledge to structuring;

- Contextual learning.

As a summary of this section, all of these situation models reflect the general aspect of the situation, its entities and the interactions between these different entities. These models represent the situation as a teaching situation rather than a learning situation. These types of modelling agree on the fact that a classroom learning situation integrates four interacting components: the learner, the teacher, the context and the teaching material, which can be interesting at first for designers of e-learning learning situations.

In the case of distance learning, the models presented, although they may provide additional information regarding the consideration of cognitive and metacognitive processes in the structuring, organization and implementation of databases on learning situations, they do not provide enough data or clear algorithms for programmers and IT developers of IT systems and e-learning tutors, especially when it comes to alying a training aroach of adults by situations.

\subsection{Towards a modelling of learning situations located using the Vee diagram.}

\subsubsection{The Vee diagram and its use in education}

The Vee diagram got its name from its "V" shape. It makes it possible to visualize a complex situation. Concretely, it makes it possible to structure a learning situation around a problem to be solved or a key question, by articulating the theoretical basis and precise processing procedures in a well-defined context. It is therefore both a heuristic procedure diagram, a knowledge structuring diagram and an explicit declaration diagram [51].

The Vee diagram was originally designed by Gowin in 1970 [52]. This diagram inspires its theoretical foundations in Ausubel's theory of meaningful learning and the development of work on learner performance in problem solving in science. In its original form, the Vee diagram incorporates two branches "Thinking" \& "Doing" and an area of interactions between the two branches. The conceptual part "Thinking" includes theories, principles, concepts, etc. and the part of the Vee "Doing" includes methodological tools. The following figure illustrates this model.

Research on the use of the Vee diagram in education and training is extensive. The original diagram has been altered many times and evaluated by research in many ways. This research has shown that the Vee digram is one of the effective tools that allows the development of metacognitive skills, meaningful learning, or critical thinking in adults in training $[51,53,54,55]$. 


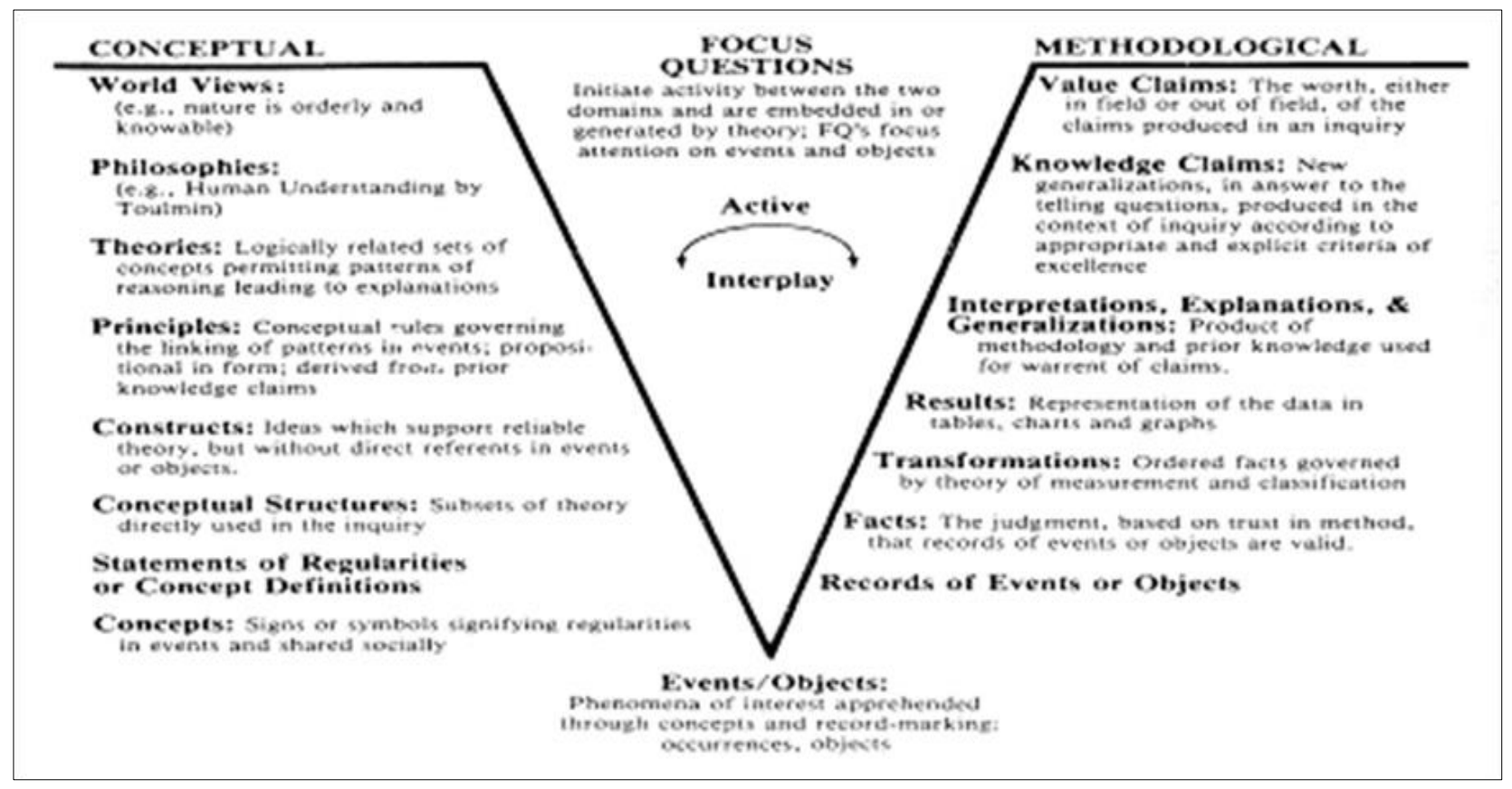

Figure 6 Gowin's epistemological Vee [52]

The use of the Vee diagram in learning makes it possible to establish significant links between prerequisite knowledge and new knowledge, to develop communication skills between learners in a collaborative situation [56, 57]. The Vee diagram can be used to implement inquiry and inquiry-based learning modes [58].

\subsubsection{Proposition d'un modèle de situation d'arentissage situé et sa modélisation à l'aide du diagramme Vee}

In this research work, we propose a model of a learning-process situation, from a situated learning perspective, composed of three entities: thinking processes, methodological processes and process transformations. And to explicitly capture the different cognitive, metacognitive and communicative processes that can be involved in adult online learning, we will use the modified Vee diagram, shown in Figure 7

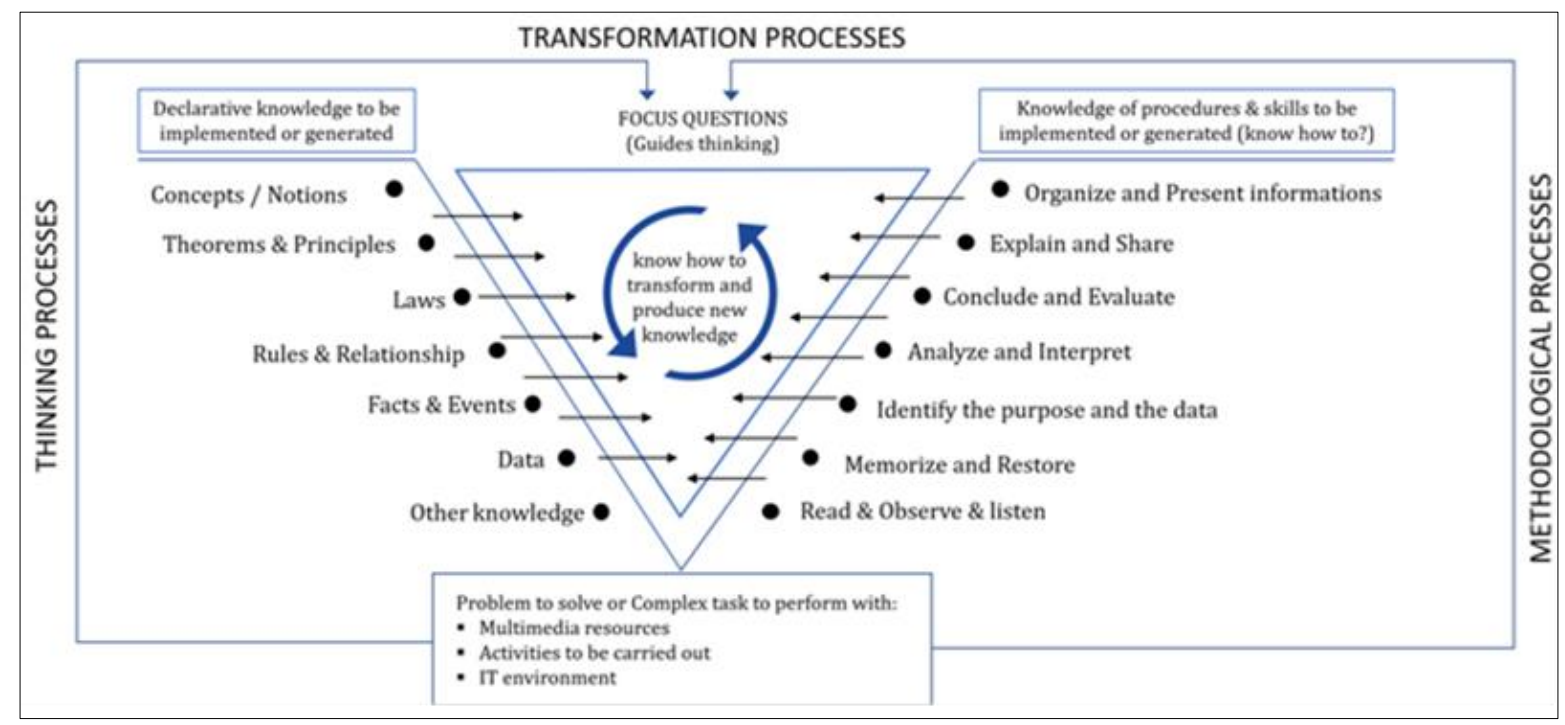

Figure 7 Modeling of the learning stuation with modified vee diagram of gowin

The branch on the right refers to the different knowledge or declarative knowledge involved in or by the problem to be solved (or the complex task to be performed). This knowledge calls on the processes of memorization, restitution and conceptualization. The branch on the left presents all the procedures and methodological skills to be implemented to deal effectively with the problem to be solved. The inner triangle brings together the different interactions between the 
two branches (networks of transformations and the production of new knowledge, in order to master the problem and find the solution.

The advantage of this modelling and the advantage of using the Vee diagram is that it can give more visibility to developers of computer systems and tutors to the extent that it allows to specify upstream the nature of the "object of the situation (problem or complex task to be solved by specifying the resources to be exploited, the tasks to be carried out, the context which gives meaning to the situation, etc.), the knowledge to be put in place or to be generated, the cognitive and metacognitive skills to implement or generate, the various transformations to perform and the solution to find.

Each learning situation is implemented in the system according to precise algorithms, which will allow the tutor system, once the adult learner begins to deal with a situation of his choice, to follow in the footsteps of his collaborative activities, his reasoning, the knowledge and skills generated and the transformations it carries out, obviously in relation to the model of the situation available to the system.

\section{Conclusion}

Teaching / training / learning situation models can be useful and carry relevant information for teachers and trainers in their conceptions of learning situations. However, we believe that these situation models do not make it possible to account for the different processes that a designer (modelling phase) or a developer (coding and implementation phase) of e-learning learning needs to know in order to put into practice. Place an intelligent tutor system or expert system.

The learning context model represented by the Vee diagram will focus on the process to be developed in the e-learning learning process by fixing the nature of the contextual object and the knowledge to be learned upstream, the implementation or generation, the cognitive and metacognitive skills to be implemented or generated, the various transformations to be made, and the solutions to be found.

Each learning situation is implemented in the system according to a precise algorithm, which will allow the tutor system, once the adult begins to face the situation he chooses, to follow in the footsteps of his collaborative activities, of its reasoning, of its knowledge and skills generated and the conversion carried out is obviously linked to the situation model available in the system.

Our next article will be devoted to the choices, the development process, the modeling language and the development languages and tools as well as the development of our system.

\section{Compliance with ethical standards}

\section{Acknowledgments}

This paper and the research behind it would not have been possible without the exceptional support of my supervisors, Erradi Mohamed and Khaldi Mohamed. Their enthusiasm, knowledge and exacting attention to detail have been an inspiration and kept my work on track. Erradi Omar and Khaldi Maha, my colleagues at Abdel Malek University, have also helped over our researches and answered with unfailing patience numerous questions about the topic.

\section{Disclosure of conflict of interest}

The authors declare that they have no conflict of interest.

\section{References}

[1] Brougère G. « De l'arentissage diffus ou informel à l'éducation diffuse ou informelle ». Le Télémaque, $\mathrm{n}^{\circ} .2016$; 49(1): 51-63.

[2] Sockett G. The Online Informal Learning of English. London: Palgrave Macmillan. 2014.

[3] Tudor SL. « Formal - Non-formal - Informal in Education ». Procedia - Social and Behavioral Sciences, $\mathrm{n}^{\circ}$. 2013; 76: 821-826.

[4] Le Gall D, Besnard J, Havet V, Pinon K, Allain P. Contrôle exécutif, cognition sociale, émotions et métacognition. Revue de neuropsychologie. 2009; 1: 24-33. 
[5] Astier P. (Éd.). Les acquis de l’expérience. Éducation Permanente. 2004; 158: 159.

[6] Colardyn D, Bjornavold J. Validation of formal, non-formal and informal learning: policy and practices in EU member states. European Journal of Education. 2004; 39: 1.

[7] Jonnaert Ph. (Dir.). Aroche par situations - Matrice du traitement compétent d'une situation. Cahiers de la CUDC, (1010)5, numéro thématique. En ligne. 2010.

[8] Bertrand Y. Théories contemporaines de l'éducation. Lyon: Chronique Sociale. 1993.

[9] Richard-Emmanuel Eastes. Processus d'arentissage, savoirs complexes et traitement de information: un modèle théorique à l'usage des praticiens, entre sciences cognitives, didactique et philosophie des sciences. Philosophie. Université Panthéon-Sorbonne - Paris I; Université de Genève. 2013.

[10] JOHSUA S. \& DUPIN JJ. Introduction à la didactique des sciences et des mathématiques, PUF, Paris. 1993.

[11] Simbagoye A. Aroche par les situations et intégration des TIC dans l'enseignement arentissage du français langue d'enseignement à l'élémentaire. Dans: Claude Daviau Éd. Écoles en mouvements et réformes: Enjeux, défis et perspectives (. 159-174). Louvain-la-Neuve, Belgique: De Boeck Supérieur. 2012.

[12] Ghisla G, Boldrini E, Bausch L. DPS-Didactique par situations: UN guide pour les enseignants de la formation professionnelle. Institut fédéral des hautes études en formation professionnelle. Suisse. 2014.

[13] Écalle J, Magnan A. Effets du contexte. Dan's:, J. Écalle \& A. Magnan (Dir), L'arentissage de la lecture et ses difficultés. 2015; 197-222.

[14] Johnny Jacinta. Contextual Learning: A Model for Learning \& Instruction in Math. 2008.

[15] Selvianiresa D, Prabawanto S. Contextual Teaching and Learning Aroach of Mathematics in Primary Schools. Journal of Physics: Conference Series, 895, International Conference on Mathematics and Science Education. 2017.

[16] Laville F. La cognition située. Une nouvelle aroche de la rationalité limitée. In: Revue économique. 2000; 51nº (6): 1301-1331.

[17] P Cobb. Situated Cognition: Contemporary Developments. Editor(s): Neil J. Smelser, Paul B. Baltes, International Encyclopedia of the Social \& Behavioral Sciences, Pergamon. 2001; 14121-14126

[18] Ataizi M. Situated Cognition. In: Seel N.M. (eds) Encyclopedia of the Sciences of Learning. Springer, Boston, MA. 2012.

[19] Weinberg A. La cognition située. Dan's: Jean-François Dortier éd., Le cerveau et la pensée: Le nouvel âge des sciences cognitives (. 42-44). Auxerre, France: Éditions Sciences Humaines. 2014.

[20] Brown JS, A Collins, P Duguid. "Situated Cognition and Culture of Learning” in Educational Researcher. 1989; 18(1): 32-42.

[21] Lave J, E Wenger. “Situated Learning: Legitimate Peripheral Participation”. Cambridge, England: Cambridge University Press. 1991.

[22] Greiffenhagen C, W Sharrock. School mathematics and its everyday other? RevisitingLave's 'Cognition in Practice'. Educational Studies in Mathematics. 2008; 69(1): 1-21.

[23] Monaghan J. Situated Cognition in Mathematics Education. In: Lerman S. (eds) Encyclopedia of Mathematics Education. Springer, Dordrecht. 2014.

[24] Hansman C, Wilson A. Situating Cognition: Knowledge and Power in Context. 2002.

[25] Nikulin SG, Solovyeva NA. "Situational Tasks in Adult Education: design and diagnostics Algorithms". Journal of Environmental Treatment Techniques. 2019; 7(3): 467-473.

[26] Catherine AH. Context-Based Adult Learning. new Directions For Adult And Continuing Education, No. 89, JosseyBass, A Publishing Unit Of John Wiley \& Sons, Inc. 2001.

[27] Catherine AH, Wilson AL. "Cognition and Practice: Adult Learning Situated in Everyday Activity," Adult Education Research Conference. 1998.

[28] Brousseau G. "Les représentations: étude en théorie des situations didactiques". Revue des sciences de l'éducation. 2004; 30(2).

[29] Kurt S. "Situated Learning Theory". Educational Technology. 17 February 2021. 
[30] Stein D. “situated Learning in Adult Education”. ERIC Digest N. 1998; 195.

[31] Norainna SB. “Situated Learning Theory: the Key to effective Classroom Teaching?" International Journal for Educational, social, Political \& Cultural Studies. 2018; 1(1).

[32] Fabre M, VellasE. (Dir.). “Situations de formation et problématisation“. Brielle’s: De Boeck-University. 2006.

[33] Schroeder CM, Scott TP, Tolson H, Huang T-Y, Lee Y-H. A Meta-Analysis of National Research: Effects of Teaching Strategies on Student Achievement in Science in the United States. Journal of Research in Science Teaching. 2007; (44)10: 1436-1460.

[34] Mayes T, De Freitas S. "Learning and e-learning: the role of theory. Rethinking Pedagogy for a Digital Age: Designing and Delivering E-Learning, Beetham H. \& Sharpe R. (editors). Routledge: London. 2007.

[35] Lenoir Y, Tupin F. (Dir.). "Revisiter la notion de situation: aroches Plurielles “. Recherches en Education. 2011; 12.

[36] Faerber R. "Caractérisation des situations d'arentissage en groupe ». In: Scienc es et Technologies de l'Information et de la Communication pour l'Éducation et la Formation, volume 11, 2004. Ontologies pour les EIAH. 2004; 297-331.

[37] Hommage G. "Larches par la situation“. Collection: Les formateurs ont du talent. Editions Piriac. 2015.

[38] Astolfi JP. Placer les élèves dans une situation-problème? In Probio-Revue. 1993; 16(4): 311-321.

[39] Evéquoz G. "Les compétences clés: Pour accroître l’efficacité et l'employabilité de chacun“. Collection Entreprise et Carrières. Edition Liaisons. Paris. 2004.

[40] Sanchez Eric, Monod-Ansaldi R. Recherche collaborative orientée par la conception. UN paradigme méthodologique pour prendre en compte la complexité des situations d'enseignement-arentissage. Education \& Didactique. 2015; 9 (2): 73-94.

[41] Jacques Ginestié et André Tricot, «Activité d'élèves, activité d'enseignants en éducation scientifique et technologique », RDST [En ligne], 8 | 2013, mis en ligne le 17 février 2014, consulté le 14 juillet 2021.

[42] Dunkin MJ, Biddle BJ. The study of teaching. Holt: Rinehart \& Winston. In Green, Judith \& Joo, Jenna. (2017). Classroom Interaction, Situated Learning. 1974.

[43] Gage NL. The Scientific Basic of the Art of Teaching. New York: Teachers College Press. In Joël Clanet, « L'efficacité enseignante, quelle modélisation pour servir cette ambition? », Questions Vives [En ligne], Vol.6 n¹8 | 2012 , mis en ligne le 15 mai 2013, consulté le 14 juillet 2021. 1978.

[44] Joël Clanet, «L'efficacité enseignante, quelle modélisation pour servir cette ambition? », Questions Vives [En ligne], Vol.6 n¹8 | 2012, mis en ligne le 15 mai 2013, consulté le 14 juillet 2021. URL:

[45] Derobertmasure A, Dehon A. Development of reflexivity and decoding of the action: questions of methods. Revue Phronesis. 2012; 1(2): 24-44.

[46] Hérold J-F. UN modèle de la situation d'enseignement-arentissage pour mieux comprendre l'activité de l'élève en classe. Revue des sciences de l'éducation. 2019; 45(1): 82-107.

[47] Dumont H. et Istance D. Analysing and designing learning environments for the 21st century. Dans H. Dumont, D. Istance et F. Benavides (dir.), The nature of learning: Using research to inspire practice. Paris, France: OECD Publishing. 2010; (19-34).

[48] Cléder C, Pascal Leroux, Élise Gendron et Véronique Quanquin, « Modélisation d'une situation d'arentissage en termes de connaissances et de règles pour rendre compte de l'activité de l'élève - Étude dans le contexte de l'arentissage de la lecture en classe », Alsic [En ligne], Vol. 14 | 2011, mis en ligne le 15 mai 2011, consulté le 18 juillet 2021.

[49] Quanquin V, Chambreuil A. Modélisation pour UN environnement multimédia de l'arentissage individualisé de la lecture, Psychologie Française. March 2006; 51(1): 41-54.

[50] Maha, Khaldi, Jamal, Barhone, Erradi, Mohamed, Mohamed, Khaldi. The educational scenario architecture of a learning situation. Global Journal of Engineering and Technology Advances. 2020; 3: 27-040.

[51] Novak JD, Gowin B. Learning how to learn. Cambridge University Press. 1984.

[52] Novak J, Gowin D, Kahle J. simple Vee diagram. In learning how to learn. Cambridge University Press. 1984; 183187. 
[53] Novak J. "Concept maps and Vee diagrams: two metacognitive tools to facilitate meaningful Learning." Instructional Science. 1990; 19: 29-52.

[54] Passmore. In Fox.R.,C. «Gowin's Knowledge Vee and the Integration of Philosophy and Methodology: A Case Study. Journal of Geography in Higher Education · April 2007. 1998.

[55] Aysegul Evrena, Kaan Batia, Serkan Yilmaz. The effect of using V- diagrams in science and technology laboratory.laboratory teaching on preservice teachers' critical thinking disposition. Procedia-social and behavioral Sciences. 2012; 46: 2276-2272.

[56] Alvarez Marino C, Risko, Victoria J. "The Use Of Vee Diagrams With Third Graders As A Metacognitive Tool For Learning Science Concepts" (2007). Teaching and Learning Faculty Research. 2012; 5.

[57] Luft JA, Tollefson SJ, Roehrig GH. Using an Alternative Report Format inUndergraduate Hydrology Laboratories.Journal of Geoscience Education. 2001; 49(5): 454-460.

[58] Crien K, Archambault L, Cindy K. Using Scaffolded Vee Diagrams to Enact Inquiry Based Learning. In book: Grounded Designs for Online and Hybrid Learning: Designs in Action. 2014; 75-100. Chapter: 4. International Society for Technology in Education (ISTE); Editors: Hirumi atsusi 